\title{
A reconstruction of the recent fire regimes of Majete Wildlife Reserve, Malawi, using remote sensing
}

\author{
Willem A. Nieman ${ }^{1,2^{*}}$ (D, Brian W. van Wilgen ${ }^{3}$ and Alison J. Leslie ${ }^{1}$
}

\begin{abstract}
Background: Fire is an important process that shapes the structure and functioning of African savanna ecosystems, and managers of savanna protected areas use fire to achieve ecosystem goals. Developing appropriate fire management policies should be based on an understanding of the determinants, features, and effects of prevailing fire regimes, but this information is rarely available. In this study, we report on the use of remote sensing to develop a spatially explicit dataset on past fire regimes in Majete Wildlife Reserve, Malawi, between 2001 and 2019. Moderate Resolution Imaging Spectroradiometer (MODIS) images were used to evaluate the recent fire regime for two distinct vegetation types in Majete Wildlife Reserve, namely savanna and miombo. Additionally, a comparison was made between MODIS and Visible Infrared Imager Radiometer Suite (VIIRS) images by separately evaluating selected aspects of the fire regime between 2012 and 2019.

Results: Mean fire return intervals were four and six years for miombo and savanna vegetation, respectively, but the distribution of fire return intervals was skewed, with a large proportion of the area burning annually or biennially, and a smaller proportion experiencing much longer fire return intervals. Variation in inter-annual rainfall also resulted in longer fire return intervals during cycles of below-average rainfall. Fires were concentrated in the hot-dry season despite a management intent to restrict burning to the cool-dry season. Mean fire intensities were generally low, but many individual fires had intensities of 14 to 18 times higher than the mean, especially in the hot-dry season. The VIIRS sensors detected many fires that were overlooked by the MODIS sensors, as images were collected at a finer scale.
\end{abstract}

Conclusions: Remote sensing has provided a useful basis for reconstructing the recent fire regime of Majete Wildlife Reserve, and has highlighted a current mismatch between intended fire management goals and actual trends. Managers should re-evaluate fire policies based on our findings, setting clearly defined targets for the different vegetation types and introducing flexibility to accommodate natural variation in rainfall cycles. Local evidence of the links between fires and ecological outcomes will require further research to improve fire planning.

Keywords: fire frequency, fire intensity, fire probability, fire season, miombo, MODIS, savanna, VIIRS

\footnotetext{
* Correspondence: 17688132@sun.ac.za

'Department of Conservation Ecology and Entomology, Stellenbosch

University, Private Bag X1, Matieland, Western Cape 7602, South Africa

${ }^{2}$ Majete Research Programme, Majete Wildlife Reserve, P.O. Box 232,

Chikwawa 315100, Malawi

Full list of author information is available at the end of the article
}

\section{Springer Open}

(c) The Author(s). 2021, corrected publication 2021. Open Access This article is licensed under a Creative Commons Attribution 4.0 International License, which permits use, sharing, adaptation, distribution and reproduction in any medium or format, as long as you give appropriate credit to the original author(s) and the source, provide a link to the Creative Commons licence, and indicate if changes were made. The images or other third party material in this article are included in the article's Creative Commons licence, unless indicated otherwise in a credit line to the material. If material is not included in the article's Creative Commons licence and your intended use is not permitted by statutory regulation or exceeds the permitted use, you will need to obtain permission directly from the copyright holder. To view a copy of this licence, visit http://creativecommons.org/ licenses/by/4.0/. 


\section{Resumen}

Antecedentes: El fuego es un proceso importante que moldea la estructura y el funcionamiento de los ecosistemas de sabana africanos, y los gestores de áreas protegidas de esas sabanas usan al fuego para lograr objetivos de manejo. Desarrollar políticas apropiadas de manejo deben estar basadas en un conocimiento de los determinantes, características, y efectos de regímenes de fuego prevalentes, aunque esta información raramente está disponible. En este estudio, informamos sobre el uso de sensores remotos para desarrollar una base de datos espacialmente explícitos sobre regímenes de fuegos pasados en la reserva de vida silvestre de Majete en Malawi, entre 2001 y 2019. Imágenes del satélite MODIS (Espectroradiómetro de Imágenes de Resolución Moderada) fueron usadas para evaluar el régimen reciente de fuego para dos tipos distintos de vegetación en la Reserva de vida Silvestre de Majete, denominadas savanna y miombo. Adicionalmente fue hecha una comparación entre imágenes de MODIS y VIIRS (Radiómetro de Imágenes en el Infrarrojo Visible), mediante la evaluación por separado de aspectos seleccionados del régimen de fuego entre 2012 y 2019.

Resultados: Los intervalos medios de retorno del fuego fueron de cuatro y seis años para la vegetación del miombo y la savanna, respectivamente, aunque la distribución de los intervalos de fuego fue sesgada, con una gran proporción del área quemada en períodos anuales o bienales, y una pequeña proporción experimentando períodos de retorno del fuego mucho más largos. La variación interanual de la lluvia también resultó en períodos más largos de retorno del fuego durante ciclos de lluvias por debajo de la media. Los fuegos se concentraron en la estación cálida-seca a pesar de los intentos de manejo de restringir las quemas a los períodos secos y fríos. La intensidad media de los fuegos fue en general baja, aunque algunos fuegos individuales alcanzaron intensidades de 14 a 18 veces más alta que la media, especialmente durante la estación cálida y seca. El sensor VIIRS detectó muchos fuegos que fueron pasados por alto por el sensor MODIS, dado que las imágenes fueron colectadas en una escala más fina.

Conclusiones: Los sensores remotos proveyeron de una base muy útil para reconstruir el régimen de fuegos recientes de la reserva de vida silvestre de Majete en Malawi, y han subrayado un desfasaje corriente entre el manejo del fuego y las tendencias reales. Los gestores de recursos deberían re-evaluar las políticas de manejo del fuego basados en nuestros resultados, estableciendo metas claras y definidas para los distintos tipos de vegetación e introducir una flexibilidad para acomodar la variación natural en los ciclos de lluvias. La evidencia local de las ligazones entre los fuegos y los resultados ecológicos requerirá de más investigaciones para mejorar los planes de quemas.

\section{Abbreviations}

FRI: $\quad$ Fire Return Interval

FRP: $\quad$ Fire Radiative Power

MODIS: MODerate resolution Imaging Spectroradiometer

MW: MegaWatts

MWR: Majete Wildlife Reserve

PA: $\quad$ Protected Area

VIIRS: VIsible Imager Radiometer Suite

\section{Background}

Fire is an important process in savanna and woodland ecosystems, where it enables the coexistence of woody and herbaceous plants by affecting nutrient cycling, grass productivity, and tree recruitment (Bond and Keeley 2005; Anderson et al. 2007). Changes to prevailing fire regimes can therefore alter the structure and functioning of these ecosystems (Higgins et al. 2007). Managers of savanna ecosystems in sub-Saharan Africa have thus used fire to achieve a range of management goals for at least the past 100 years (van Wilgen 2009), and detailed information on fire regimes has been documented for a few African protected areas (PAs; Scholes and Walker 1993; van Wilgen et al. 2000; Brockett et al. 2001; Eby et al. 2015; Archibald et al. 2017). The majority of PAs, however, particularly those smaller in size, have very little or no information on past fire regimes or fire management practices. This lack of information means that decisions on whether, how, and when to use fire can only be based on general principles, rather than on an informed understanding of prevailing fire regimes and their effects in any given area (Forsyth and van Wilgen 2008). Remote sensing provides a way to significantly improve our understanding of past fire regimes in data-sparse environments and of the relationship between fire, climate, and vegetation (Goodwin and Collett 2014; Archibald and Hempson 2016).

Malawi has an extremely dense human population in comparison to the rest of sub-equatorial Africa $(\sim 200$ people $\mathrm{km}^{-2}$; NSOM UNPFA 2018), resulting in few fires occurring outside PAs due to conversion of the land to 
crops, or due to overgrazing that removes grass fuels and, as a result, $<5 \%$ of the Malawian landscape outside PAs burns annually (Archibald et al. 2010). Majete Wildlife Reserve (MWR), Malawi, was established in 1955 with the objective of restricting elephants to the reserve, but the majority of large mammals were extirpated during the 1980s and 1990s due to large-scale poaching (Morris 2006). In 2003, African Parks Ltd., together with the Malawian Department of National Parks and Wildlife, began the process of restoring, managing, and developing MWR. Since then, 2500+ individuals of 16 large-mammal species have been reintroduced to MWR from PAs in Malawi, Zambia, and South Africa. Before 2004, MWR was unfenced, and there was little to no capacity to actively manage the reserve. Consequently, there was no active fire management in place, and MWR was heavily utilized by local people for the extraction of natural resources to sustain their livelihoods. This resulted in an increased incidence of uncontrolled wildfires, sometimes ignited accidentally by people, but mostly set intentionally to clear areas for hunting and cultivation. The resulting fires were not suppressed, and a single ignition reportedly often burned for two to three weeks. Active fire management in MWR started in 2004, shortly after the commencement of the mammal reintroduction program. At this stage, management fires were solely conducted along the outer fences to prevent fires from entering the reserve from outside. In 2007, prescribed burning was extended by burning fire breaks along the main roads. In 2011, a system of cool-dry season (May to July) prescribed burning was implemented in which point-ignited fires were set along roads in areas where the grass biomass was $>4000 \mathrm{~kg} \mathrm{ha}^{-1}$. No fires were allowed to be ignited after July, and $50 \%$ of the reserve was allowed to burn per annum while all unplanned fires were actively suppressed. In 2014, the maximum target area to be burned was reduced to $30 \%$. Also in 2014, prescribed fires were additionally set for the control of invasive alien plants along the banks of the Shire River, notably for the control of Lantana camara L. The majority of mammal reintroductions were made in the northeastern section of MWR. Fires were actively suppressed in this area to protect the animals, people, and infrastructure, and to reduce large unsightly burns in tourist areas.

Our research provides a spatially explicit assessment of the recent fire regime of MWR between 2001 and 2019 using remote sensing. Additionally, the implications for future fire management are explored for broad vegetation types in MWR. This is intended to aid in the development of appropriate fire management practices and policies that in turn will promote the achievement of conservation goals.

\section{Methods}

Study area

The MWR (circa 70000 ha) is situated in the Lower Shire Valley, part of the Great Rift Valley in the south of Malawi. The MWR has a relatively dry tropical climate (Staub et al. 2013) that can be divided into three broad seasons: the cool-dry season (April to August), the hotdry season (September to November), and the wet season (December to March) (Hall-Martin 1972). Mean annual rainfall varies between 680 and $800 \mathrm{~mm}$ in the east, and 700 and $1000 \mathrm{~mm}$ in the west (Hall-Martin 1972). Soils are shallow, nutrient-poor lithosols, with fertile alluvial soil only occurring along a few riverbeds (Sherry 1989). The MWR is partially bordered by two perennial rivers: the Shire River in the east and the Mkulumadzi River in the northeast. These, along with ten artificial water sources and 11 natural springs, provide the only sources of water for animals during the dry season.

The dominant vegetation types for MWR were described by Sherry (1989). For the purpose of this study, MWR was divided into two broad vegetation types based on these descriptions. The broad vegetation types were lower-elevation ( 200 to $300 \mathrm{~m}$ ) savanna-woodland in the east (hereafter, savanna), and higher-elevation $(\sim 300$ to $700 \mathrm{~m}$ ) miombo-woodland in the west (hereafter, miombo) (Figs. 1 and 2). The savanna is dominated by trees in the genera Vachellia Wight \& Arn. and Senegalia Raf. (formerly Acacia Mill.), Combretum Loefl., Sclerocarya Hochst., Diospyros L., Terminalia L., and Diplorhynchus Welw. ex Ficlho \& Hiern. The miombo is dominated by trees in the genera Brachystegia Benth. and Julbernadia Pellegr. Grasses occur as an understory of variable cover below the trees, or in open areas between trees, but grasses are scarce in the northern section of savanna, where most of the ground layer consists of non-woody forbs.

A variety of large herbivorous mammal species that affect the structure of vegetation occur in MWR. These include grazers (hippopotamus, Hippopotamus amphibious Linnaeus, 1758; buffalo, Syncerus caffer Sparrman, 1779; sable antelope, Hippotragus niger Harris, 1838; waterbuck, Kobus ellipsiprymnus Ogilby, 1833; warthog, Phacochoerus africanus Gmelin, 1788; and zebra, Equus quagga Boddaert, 1785), browsers (black rhinoceros, Diceros bicornis Linnaeus, 1758; giraffe, Giraffa camelopardalis Linnaeus, 1758; and kudu, Tragelaphus strepsiceros Pallas, 1766), and mixed feeders (elephant, Loxodonta africana Blumenbach, 1797; eland, Tragelaphus oryx Pallas, 1766; impala, Aepyceros melampus Lichtenstein, 1812; and nyala, Tragelaphus angasii Angas, 1849). 


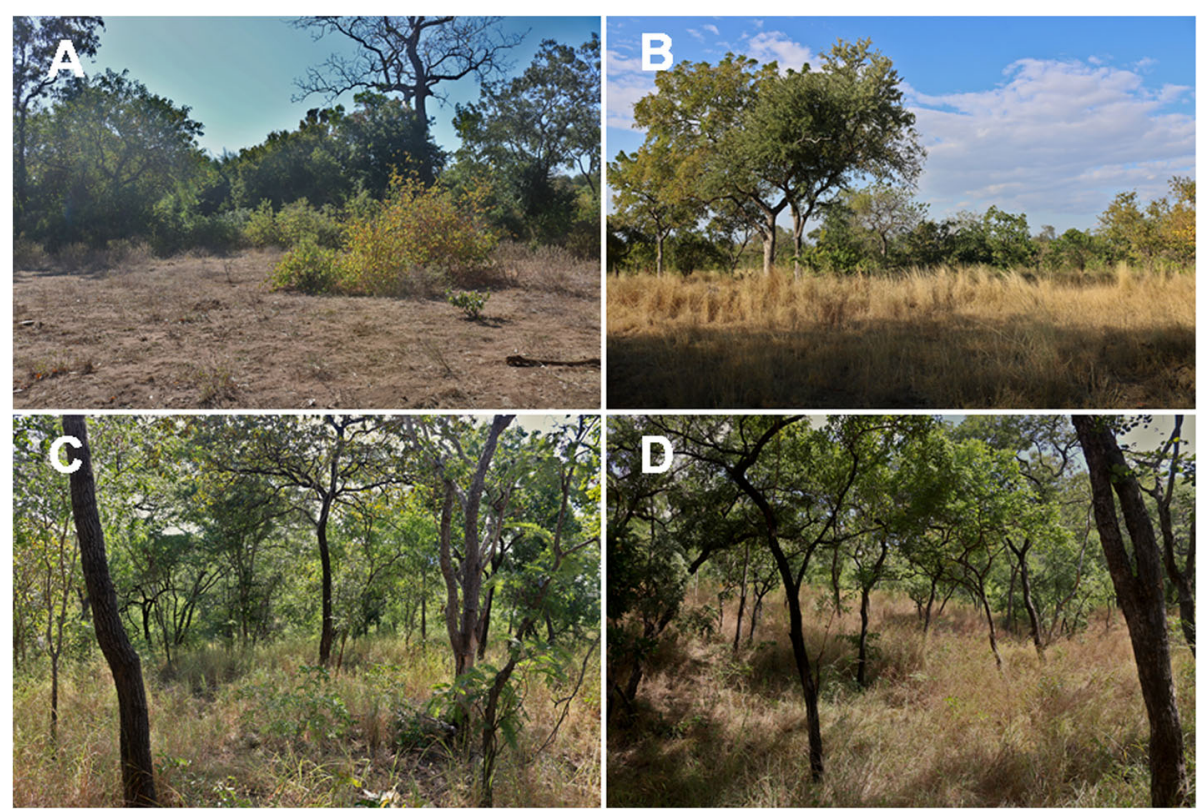

Fig. 1 Broad vegetation types of Majete Wildlife Reserve, Malawi. (A, B) Savanna (note in A the decrease in grass, and increase in non-woody forbs, due to intense grazing pressure). (C, D) Miombo. Photographer credit: W.A. Nieman (2020)
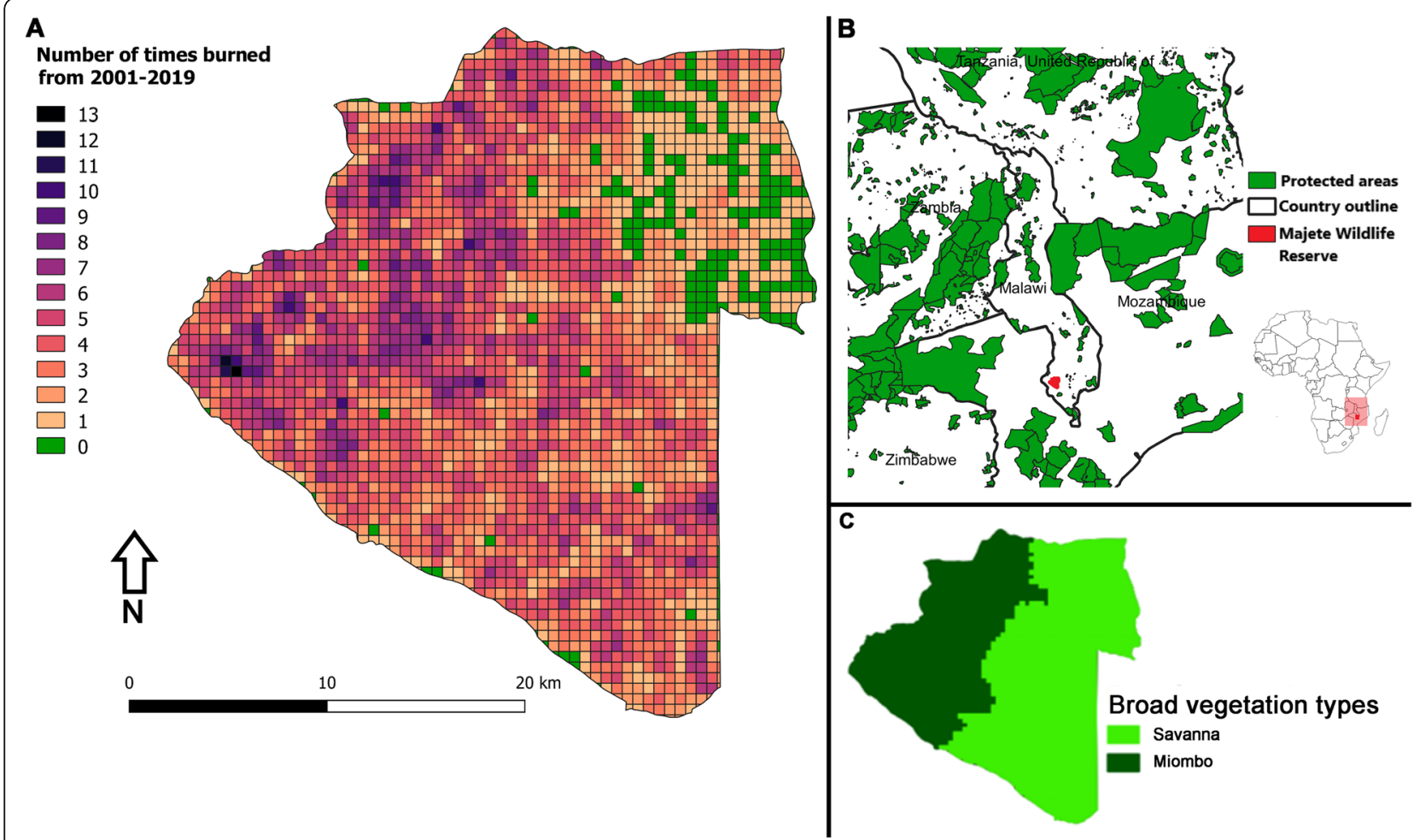

Fig. 2 (A) Fire frequency (number of times burned between 2001 and 2019) calculated for 30 ha grid cells in Majete Wildlife Reserve, Malawi. Fire return intervals are shorter (i.e., fires are more frequent) in darker grid cells, and longer in lightly shaded grid cells. (B) Surrounding countries and protected areas. (C) A simplified vegetation map showing two broad vegetation types of Majete Wildlife Reserve. The vegetation map was based on plant distributions compiled by Sherry (1989) 


\section{Fire information database}

Fire occurrence data for MWR were obtained from Moderate Resolution Imaging Spectroradiometer (MODIS) images between January 2001 and December 2019, as well as from Visible Infrared Imager Radiometer Suite (VIIRS) images between January 2012 and December 2019. Specifically, the MCD14DL near real-time hotspot (MODIS Collection 6 NRT Hotspot / Active Fire Detections MCD14DL; https:// earthdata.nasa.gov/firms), MCD45A1 burned area (Giglio et al. 2018a), and VNP14IMGT active fire detection (NRT VIIRS $375 \mathrm{~m}$ Active Fire product; https://earthdata.nasa.gov/firms) products were used. Although newer versions of the MCD45A1 product exist, the MCD45A1 algorithm has been shown to be more accurate at a finer scale, and more effective in mountainous terrain (Fornacca et al. 2017). The MODIS database was also chosen because it provided an appropriate temporal resolution by capturing fires on a daily basis. From these images, the location of burned areas can clearly be seen, and since the images are taken on a daily basis, the date that the fire started can be established by noting the first date that the burned area appears. The MODIS terra instruments started collecting data in April 2000 and can reliably detect flaming or smoldering fires of greater than $\sim 1000 \mathrm{~m}^{2}$. The VIIRS instruments started collecting information in January 2012, with a much higher spatial resolution $\left(375 \mathrm{~m}^{2}\right)$ than the MODIS sensors, and were thus able to detect smaller fires. The analyses reported in this paper are based on the MODIS data for the period 2001 to 2019. Selected analyses were also repeated to compare MODIS with VIIRS data for the period 2012 to 2019. The VIIRS dataset should reveal smaller fires typically overlooked by the MODIS sensors. The MODIS information captured in 2000 was not considered since data collection did not span the full year. Due to technical errors on the MODIS satellite, burned area data for June 2001 were unavailable. We therefore patched the data for June 2001 with estimates based on the values for June in other years, expressed as a ratio of the values for areas burned in other months (Archibald et al. 2010). Information from both sensors was captured and analyzed in a geographic information system (QGIS v3.10.2; http://www.qgis.org), and further statistical analyses were performed in RStudio v1.2.5 (RStudio Team 2020). Management records of past fires in MWR were incomplete, and thus not suitable for use in any analyses.

\section{Fire frequency and fire probability}

The mean fire return interval (FRI) of MWR was calculated as:

$$
F R I=y /(b / a)
$$

where $F R I$ is the fire return interval in years, $y$ is the number of years over which fires were recorded, $b$ is the extent of all fires over $y$ years, and $a$ is the area over which fires were recorded (van Wilgen et al. 2004). This statistic was calculated for the entire MWR, as well as for the two broad vegetation types by overlaying the fire records on a vegetation map.

Equation 1 gives a single value for FRI, but intervals can vary considerably between successive fires. An estimation of this variability is therefore required. We estimated the fire frequency distribution around the mean based on 30 ha grid cells. A grid cell was considered burned in any given year if $>30 \%$ of the cell burned. We then noted the length of FRIs between successive fires on each 30 ha grid cell. We discarded those cells that never burned (or only burned once, and thus had no FRI), and counted the number of times that fire return intervals of $1,2,3 \ldots n$ years occurred in the remaining cells (where $n=$ the number of years for which data were available). These data were then used to depict the proportion of the area of all fires on record that occurred at discrete FRIs. We also constructed curves depicting the probability of a grid cell experiencing a subsequent fire at different post-fire ages, for MWR as a whole, and for each of the two broad vegetation types, taking into account that a proportion of the area remained fire free, or only burned once, during the period examined.

\section{Influence of inter-annual rainfall variability on area burned}

Total annual rainfall can be highly variable between years in many African savanna environments. Years with relatively high rainfall promote the growth of grasses, which in turn provide more fuel for fires; the area that burns in any given year is thus strongly influenced by preceding rainfall (van Wilgen et al. 2004; Archibald et al. 2009). We obtained total rainfall for each year from 1999 to 2018 for the $4755 \mathrm{~km}^{2}$ Chikwawa region in which MWR is situated (https://climateknowledgeportal. worldbank.org). A linear regression was then used to examine the relationship between the area burned each year and the mean rainfall over the preceding two years.

\section{Fire seasonality}

The total area that burned during each month was calculated, and the findings were interpreted in terms of the three broad seasons (wet season, cool-dry season, and hot-dry season). Comparisons were made using a Kruskal-Wallis $\mathrm{H}$ test (Kruskal and Wallis 1952), followed by a post hoc Wilcoxon rank sum test (Wilcoxon 
1945). $P$-values were not adjusted and were considered significant when $P<0.05$.

\section{Fire intensity}

The fire radiative power (FRP) estimate that is captured by the satellite instrument's middle-infrared wavelength measurements represents the rate of radiant heat output from a fire in megawatts (MW; Kaufman et al. 1996). A single value of the FRP is given for each individual fire, and not per grid cell, irrespective of the period over which the fire remained active, and is captured at the time of satellite overpass. A mean was then calculated for all fires that occurred in each month and season. The FRP can be associated with both fire intensity and the rate of fuel consumption from a fire (Wooster et al. 2005; Ichoku et al. 2008; Barrett and Kasischke 2013; Wooster et al. 2013). A high FRP value is thus associated with high-intensity fires, which are typically larger in size (Rogers et al. 2015). The intensity of fires (derived from the FRP value) occurring in different seasons and in individual months in MWR were analyzed using a Kruskal-Wallis $\mathrm{H}$ test. Post hoc comparisons were made with the use of Wilcoxon rank sum tests. The $P$-values were not adjusted and were considered significant when $P<0.05$.

\section{Comparison of MODIS and VIIRS datasets}

To compare the values given by the MODIS and VIIRS sensors for the period 2012 to 2019, the FRI, fire season, and fire intensity was calculated for each dataset separately. The same methodology and statistical analyses as described in the sections above for the MODIS (2001 to 2019) dataset were used. The number of fires and the area burned detected by each sensor during 2012 to 2019 was also compared.

\section{Results}

\section{Fire frequency and probability}

A large number of fires occurred in each year in MWR over the 19-year study period, averaging 153 fires per year. Fires covered 282900 ha over the 19 years in the $\sim 70000$ ha MWR, giving an average of 14889 ha burned per year. The estimated mean FRI for the entire MWR was 5.02 yr. Mean FRIs differed between broad vegetation types, as well as between individual grid cells $(n=2524$; Fig. 2). Miombo (FRI $\mathrm{Fean}=4.05 \mathrm{yr})$ burned more frequently than savanna $\left(\mathrm{FRI}_{\text {mean }}=5.94 \mathrm{yr}\right)$.

A large proportion of the area of all fires on record burned either one $(27.8 \%)$ or two $(29.2 \%)$ years after a preceding fire, and an additional $30.6 \%$ of the area burned within three to five years after the preceding fire. Estimates of cumulative fire probability indicate that $21.7 \%$ of MWR experienced a subsequent fire after one year, while $44.2 \%$ experienced a subsequent fire after two years (Fig. 3). Note that the difference between the two estimates of area that burn annually $(27.8 \%$ and $21.7 \%$ ) is because the first is expressed as a percentage of burned area, and the second as a percentage of the area of MWR, some of which did not burn at all. The median probability of fire (i.e., the post-fire age at which $50 \%$ of the area will experience a subsequent fire) was $2.6 \mathrm{yr}$, but the distribution is highly skewed and, although short-interval fires predominate, some of the area survives for five years or more without burning, increasing the mean FRI. In addition, $22.9 \%$ of MWR experienced only a single fire, or remained fire free, for the entire study period.

At the level of individual vegetation types, it is clear that miombo burns more frequently than savanna (Table 1, Fig. 3). In miombo, almost two thirds of the area that burned either experienced a fire every year or every two years, while this was less than half in savannas. The median probability of fire was $1.7 \mathrm{yr}$ in miombo and $4.9 \mathrm{yr}$ in savanna, and a relatively large proportion $(37.0 \%)$ of savanna experienced only a single fire, or remained fire free, for the entire study period. The corresponding estimate for miombo was only $2.1 \%$.

\section{Influence of inter-annual rainfall variability on area burned}

The total rainfall recorded in individual years between 1999 and 2018 ranged between 620 and $1168 \mathrm{~mm}$. The area that burned in MWR in any given year was influenced by the mean rainfall recorded in the preceding two years (Fig. 4; $y=44.5, x-22609, \mathrm{r}^{2}=0.30$ ), and the area burned in a given year ranged from 3900 ha (5.6\% of MWR) following a period of below-average rainfall, to 31000 ha (44.3\% of MWR) following a period of above-average rainfall.

\section{Fire seasonality}

The largest proportion of the area burned in the hot-dry season, and far less in the cool-dry season; fires were virtually absent in the wet season (Fig. 5). The mean area burned differed between seasons in both the miombo $(P<0.0001)$ and the savanna $(P<0.0001)$. In both vegetation types, most of the area burned during the hot-dry season (mean $=1919.3$ ha month ${ }^{-1}$ and 1528.1 ha month ${ }^{-1}$ in the miombo and the savanna, respectively, or $85.3 \%$ and $69.7 \%$ of the total area burned annually), with fires in the cool-dry season covering a much smaller area (mean $=328.4$ ha month $^{-1}$ or $14.6 \%$ and 655.8 ha month ${ }^{-1}$ or $29.9 \%$, respectively). Hardly any of the area burned in the wet season (mean $=2.63$ ha month $^{-1}$ or $0.1 \%$ for miombo and 7.9 ha month ${ }^{-1}$ or $0.4 \%$ for savanna). The dry months (April to November) thus accounted for 99.9\% and $99.6 \%$ of the annual burned area, for miombo and savanna, respectively. In miombo, the area burned in each of the three broad seasons differed significantly $(P<0.001)$. In 


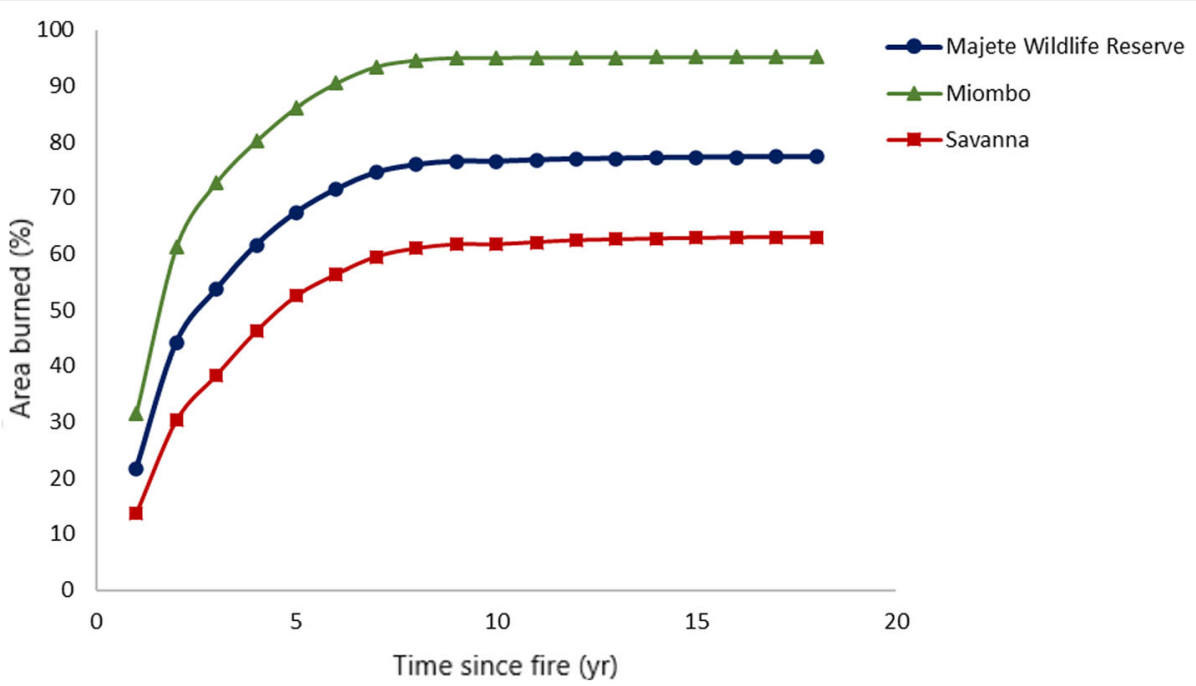

Fig. 3 The cumulative probability of a fire over time in the entire Majete Wildlife Reserve, Malawi, in miombo vegetation and in savanna vegetation, for 2001 through 2019

savanna, the area burned in the wet season differed significantly from both the hot-dry and cool-dry seasons $(P<0.0001)$, but there was no significant difference between the two dry seasons $(P>0.05)$.

\section{Fire intensity}

The mean intensity of fires was highest in the hot-dry season, and lower in the cool-dry and the wet seasons (Fig. 6). There was significant variation in FRP values between seasons in miombo $(P<0.01)$, with the highestintensity fires occurring in the hot-dry season (mean = 47.6, $\mathrm{SE}=2.2 \mathrm{MW}$ ), followed by the cool-dry season $($ mean $=33.9, \mathrm{SE}=1.9 \mathrm{MW})$ and the wet season (mean $=29.7, \mathrm{SE}=6.0 \mathrm{MW})$. The mean FRP was significantly higher in the hot-dry season than in the other seasons $(P<0.01)$, but did not differ between fires in the cool-dry and wet seasons $(P>0.05)$. The FRP values did not differ significantly between seasons in savanna $(P>0.05)$, but occasional high-intensity fires did occur, particularly at the height of the hot-dry season (October). The highest FRP values for several fires in the hot-dry season were up to 14 times greater than the mean in savanna (maximum $=781.5 \mathrm{MW}$ ), and up to 18 times greater than the mean in miombo (maximum $=$
971.1 MW). The FRP values were significantly different between individual months for both the miombo $(P<0.001)$ and savanna $(P<0.05)$ vegetation types. In miombo, the highest-intensity fires occurred in October (mean $=51.7 \pm$ $\mathrm{SE} 4.5 \mathrm{MW})$ and November $($ mean $=55.5, \mathrm{SE}=17.1 \mathrm{MW})$, while the lowest-intensity fires occurred in June (mean = 21.4, $\mathrm{SE}=3.35 \mathrm{MW}$ ). No FRP values were recorded from January through April. In savanna, the highest-intensity fires occurred in October (mean $=55.5, \mathrm{SE}=7.3 \mathrm{MW}$ ) and November $($ mean $=55.8, \mathrm{SE}=15.0 \mathrm{MW})$, while the lowestintensity fires occurred in December (mean $=24.4$, $\mathrm{SE}=9.4 \mathrm{MW}$ ). No FRP values were recorded from January through March.

\section{Comparison of the MODIS and VIIRS datasets}

More than four times as many fires (5570 fires) were detected by the VIIRS sensors over an eight-year period (2012 to 2019) than were detected by the MODIS sensors over the same period (1321 fires). Nonetheless, the MODIS sensors captured $\sim 132000$ ha of burned area from 2012 to 2019, while the VIIRS sensors captured $\sim 78000$ ha. Consequently, for the period 2012 to 2019, the estimated mean FRI for MWR from the MODIS data was $4.53 \mathrm{yr}$, compared to $7.67 \mathrm{yr}$ from the VIIRS data.

Table 1 Proportion (\%) of the area of all fires that burned at different fire return intervals in the entire Majete Wildlife Reserve, and in two broad vegetation types, in Malawi, between 2001 and 2019

\begin{tabular}{|c|c|c|c|c|c|}
\hline \multirow[b]{2}{*}{ Area } & \multicolumn{5}{|c|}{ Fire return interval } \\
\hline & $1 \mathrm{yr}(\%)$ & $2 \mathrm{yr}(\%)$ & 3 to $5 \mathrm{yr}(\%)$ & 6 to $10 \mathrm{yr}(\%)$ & $>10 \mathrm{yr}(\%)$ \\
\hline Majete Wildlife Reserve & 27.8 & 29.2 & 30.6 & 11.8 & 1.1 \\
\hline Miombo & 33.2 & 31.1 & 26.3 & 9.3 & 0.1 \\
\hline Savanna & 21.8 & 26.2 & 35.4 & 14.5 & 2.1 \\
\hline
\end{tabular}




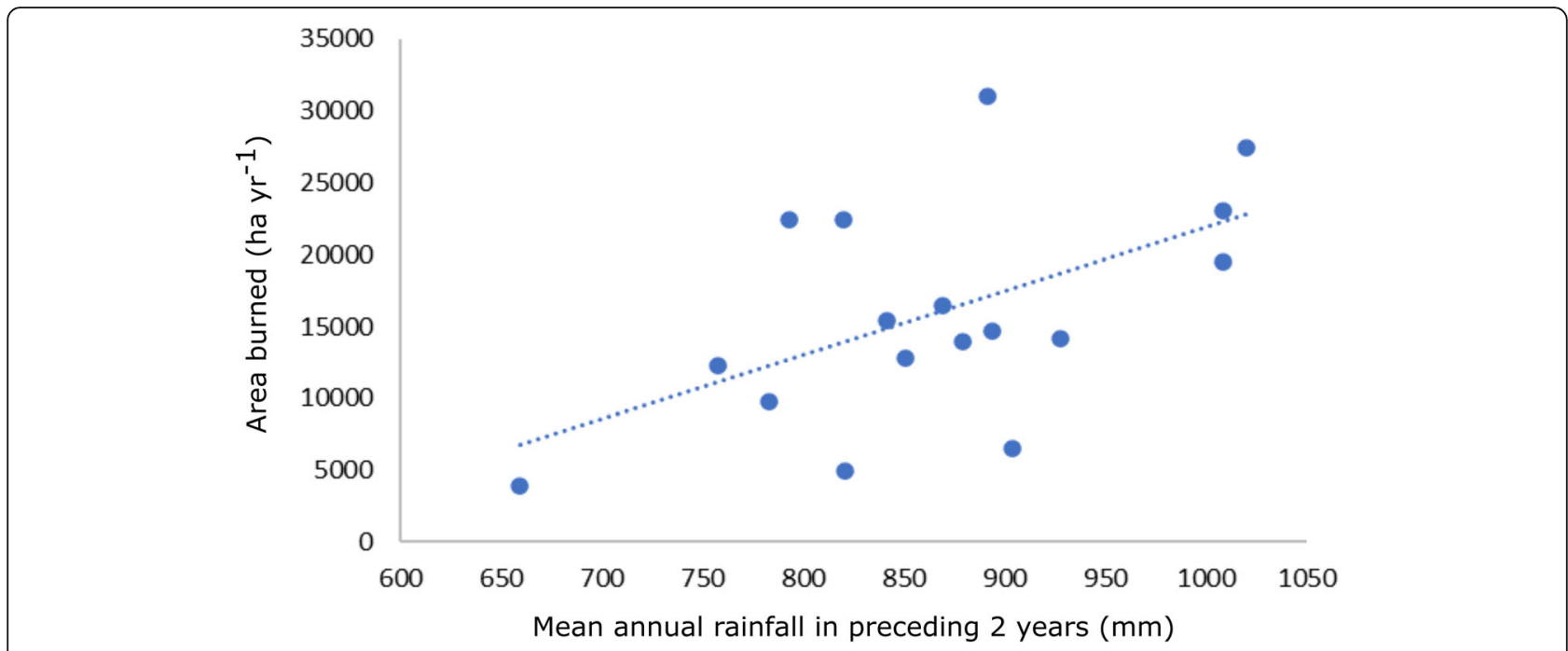

Fig. 4 Relationship between mean annual rainfall over the preceding two years and the total area burned in a given year in Majete Wildlife Reserve, Malawi for 2001 through 2019. Dots represent individual years, and the dotted line represents the overall relationship over all years

The most reliable estimate was obtained by combining both the MODIS and VIIRS datasets for 2012 to 2019, thereby capturing the highest number of fires, and was given as $2.85 \mathrm{yr}$.

The season in which fire occurred was similar between the MODIS and VIIRS datasets (Fig. 7a, b), with the most area burned in the hot-dry season $(66.1 \%$ and $66.9 \%$, respectively). A similar estimated proportion of area burned was also detected in the cool-dry season (33.5\% and $32.7 \%$, for MODIS and VIIRS, respectively), while the area burned in the wet season was consistently low in both datasets $(0.4 \%$ and $0.4 \%$, for MODIS and VIIRS, respectively). The MODIS sensors gave a much larger estimate of area burned for each month (mean $=688.0$ ha) compared to the VIIRS sensors $($ mean $=406.1$ ha $)$. For both datasets, area burned in the wet season differed significantly from both the cooldry and hot-dry seasons $(P<0.0001)$, but the cool-dry and hot-dry seasons were not significantly different from each other $(P>0.05)$. There was significant variation in the area burned in different months for both the MODIS $(P<0.0001)$ and VIIRS $(P<0.0001)$ datasets. From both datasets, most
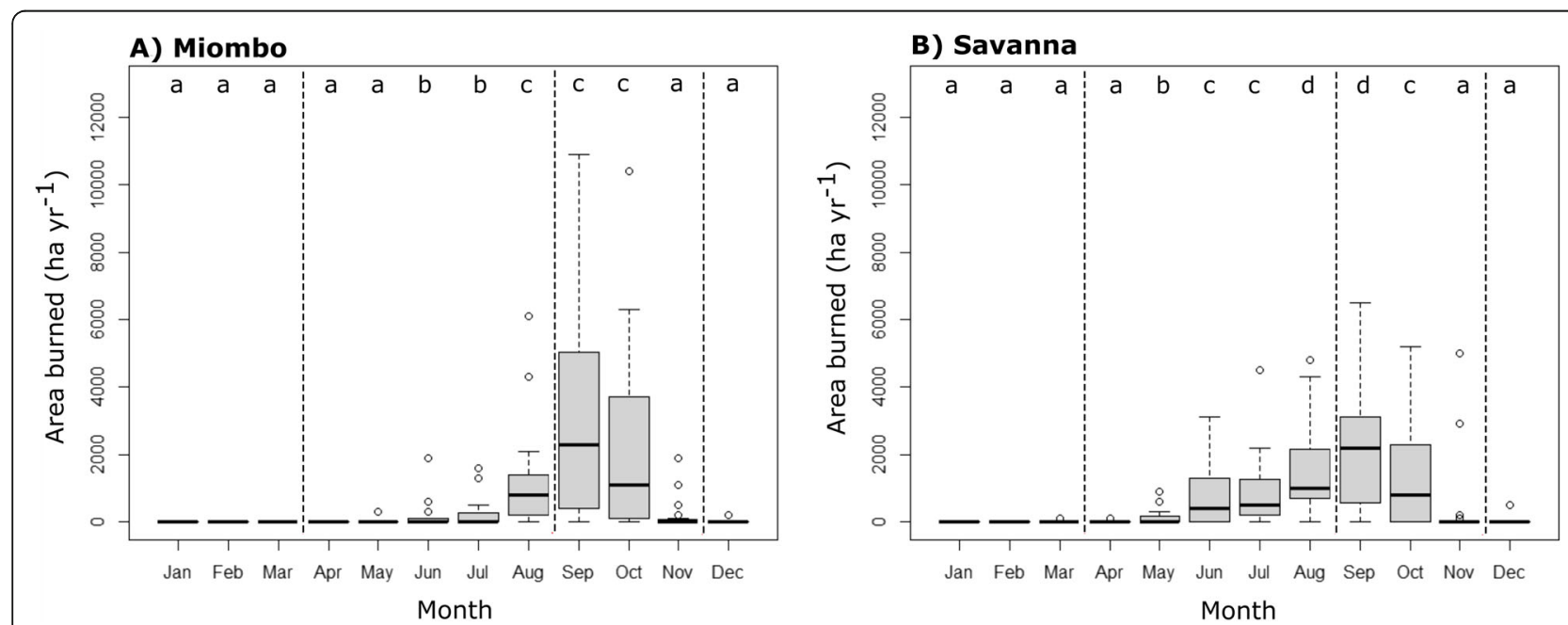

Fig. 5 The area burned in Majete Wildlife Reserve, Malawi, per month in (A) miombo and (B) savanna, based on the MODIS dataset (2001 to 2019). Box and whisker diagrams indicate the median, and $25^{\text {th }}$ and $75^{\text {th }}$ percentiles, respectively; open circles show outliers. Dotted lines indicate seasonal thresholds, and significant differences between months revealed by Wilcoxon post hoc rank sum test are denoted by letters a through $d$ 

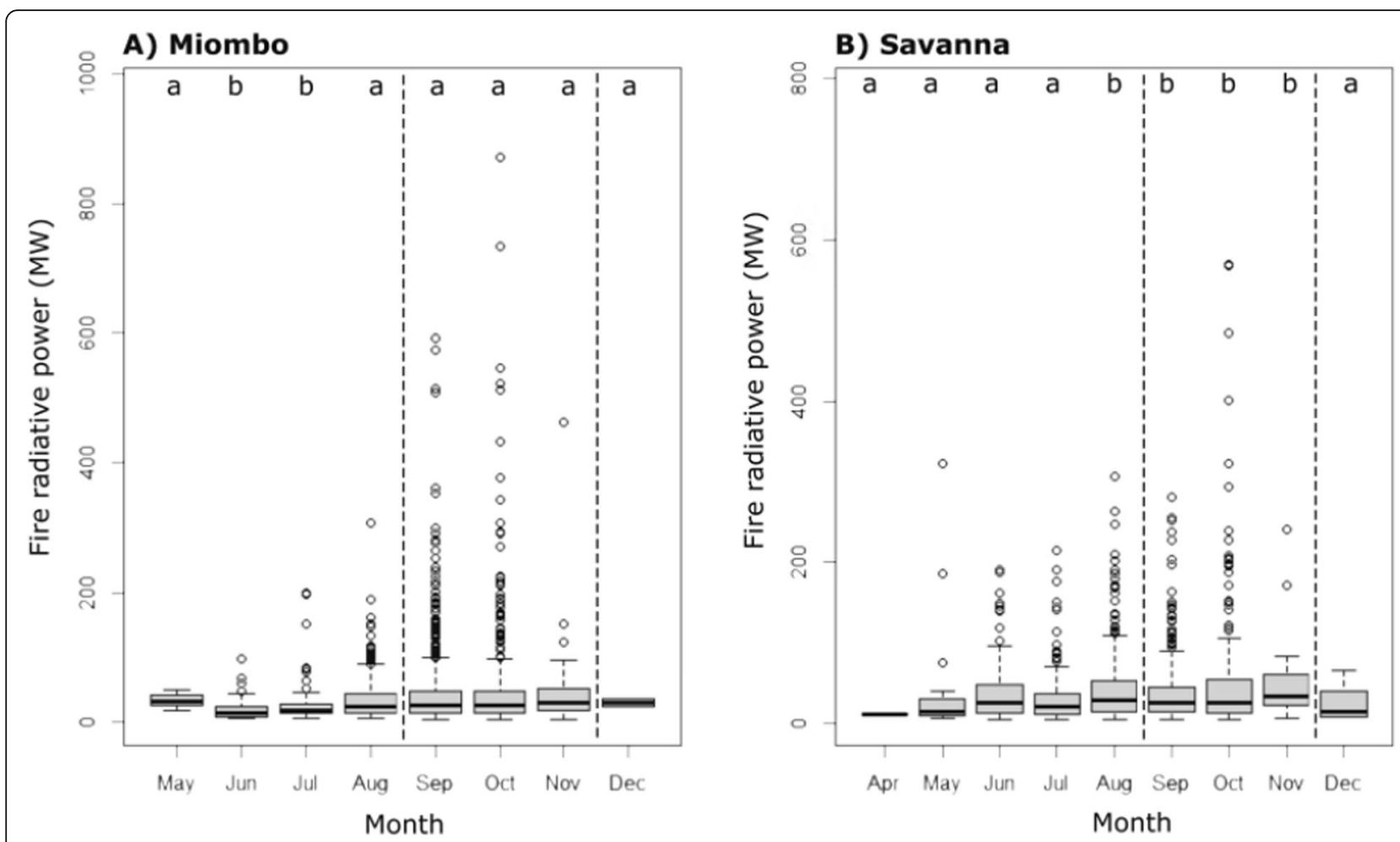

Fig. 6 Estimated fire intensity (fire radiative power, FRP) in Majete Wildlife Reserve, Malawi, per month for (A) miombo and (B) savanna, based on the MODIS dataset (2001 to 2019). Box and whisker diagrams indicate the median, and $25^{\text {th }}$ and $75^{\text {th }}$ percentiles, respectively; open circles show outliers. No FRP values were recorded from January through March in savanna, or from January through April for miombo. Dotted lines indicate seasonal thresholds, and significant differences between months revealed by Wilcoxon post hoc rank sum test are denoted by letters a and $b$

area burned in September (34.5\% and 31.0\%, for MODIS and VIIRS, respectively) and October $(29.1 \%$ and $33.4 \%$, for MODIS and VIIRS, respectively).

Similarly, both the MODIS and VIIRS sensors recorded the highest fire intensities in the late dry seasons between 2012 and 2019, but much higher values were given by the MODIS sensors (Fig. 7c, d). There was significant variation in FRP values between seasons in both the MODIS $(P<0.0001)$ and VIIRS $(P<0.0001)$ datasets, with the highest-intensity fires occurring in the hot-dry season $($ mean = 51.0, $\mathrm{SE}=\mathrm{MW}$; and 9.7, $\mathrm{SE}=\mathrm{MW}$, respectively $)$, followed by the cool-dry season (mean $=35.1, \mathrm{SE}=1.8$ MW; and 9.0, SE $=0.3 \mathrm{MW}$, respectively). Comparatively lower FRP values were additionally recorded in the wet season $($ mean $=16.3, \mathrm{SE}=6.0 \mathrm{MW}$; and 3.6, $\mathrm{SE}=0.8$ MW, for MODIS and VIIRS, respectively). Post hoc comparisons revealed that all seasons were different from each other $(P<0.01)$. The FRP values were also significantly different between individual months in both the MODIS $(P<0.0001)$ and VIIRS $(P<0.0001)$ datasets. In MODIS, the highest-intensity fires occurred in November (mean = 68.8, $\mathrm{SE}=2.7 \mathrm{MW}$ ) and October (mean $=58.4$, $\mathrm{SE}=$ 1.6 MW), while the lowest-intensity fires occurred in May $($ mean $=13.3, \mathrm{SE}=0.4 \mathrm{MW})$. In VIIRS, the highest-intensity fires occurred in October (mean =
10.0, $\mathrm{SE}=2.1 \mathrm{MW})$ and September $($ mean $=9.5 \pm \mathrm{SE}$ 3.1 MW), while the lowest-intensity fires occurred in December $($ mean $=3.6, \mathrm{SE}=0.2 \mathrm{MW})$.

\section{Discussion}

\section{Current fire regime goals of Majete Wildlife Reserve}

Fire is an important ecological process in African savannas, and managers use fire to achieve various outcomes (van Wilgen 2009). Decisions on how and when to use fire effectively should ideally be based on a sound understanding of the ecological effects of changing elements of the fire regime. In addition, plans to manage fire over large natural areas with limited capacity must be realistic and take practical constraints into account. The current goals of fire management in MWR were formulated without a detailed understanding of the current fire regime or its effects. The current goal of implementing a regime of low-intensity, patchy prescribed burns in the cool-dry season, while suppressing unplanned wildfires in the hot-dry season are currently not being achieved. The reasons for promoting a regime dominated by low-intensity fire in the cool-dry season are not explicitly spelled out in any policy documents, but they presumably include the safety of burning crews and a desire to avoid large uncontrolled fires that would 

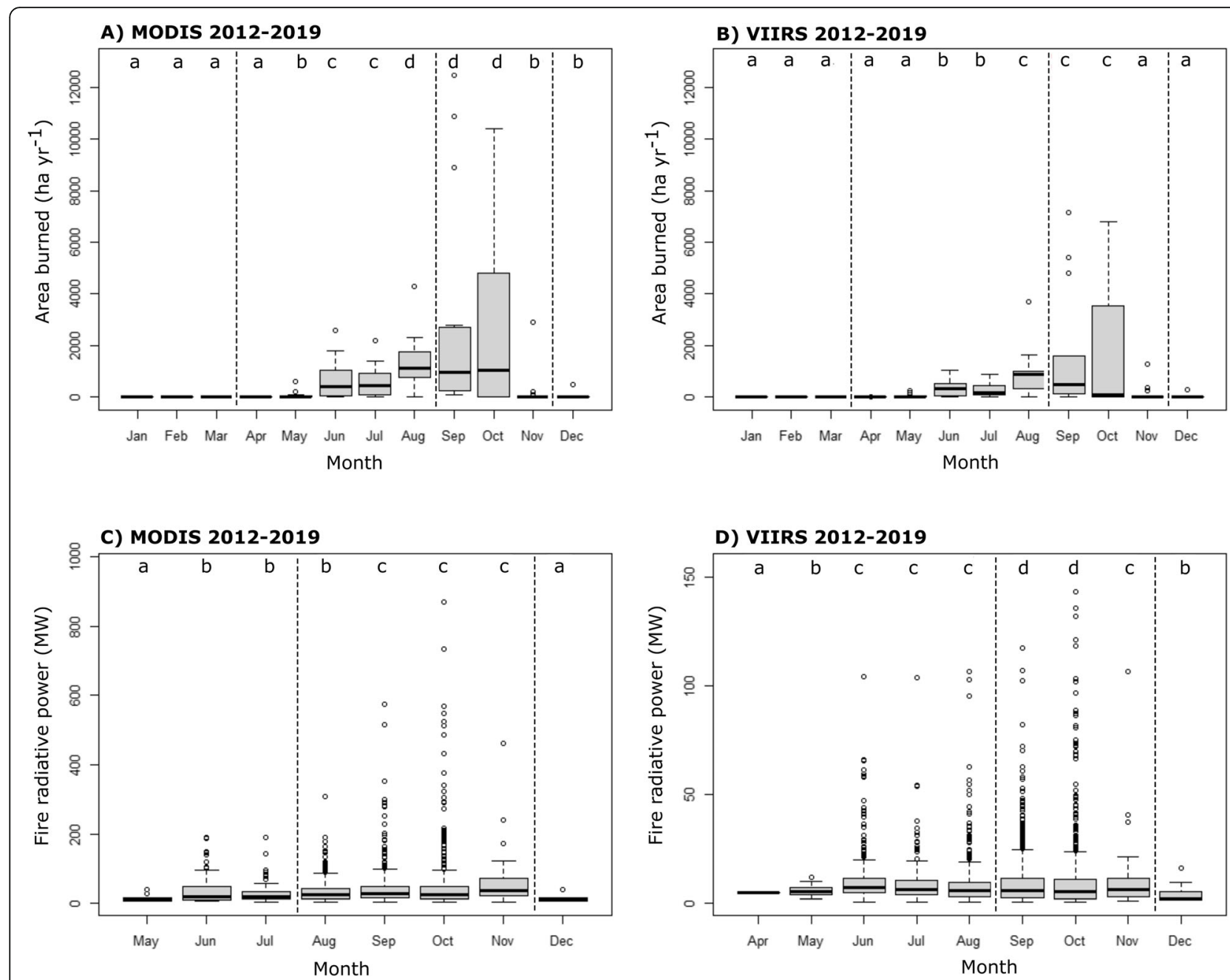

Fig. 7 A comparison of the area burned in Majete Wildlife Reserve< Malawi, per month from 2012 to 2019 based on the (A) MODIS and (B) VIIRS datasets, as well as the estimated fire intensity (fire radiative power, FRP) per month from 2012 to 2019 based on the (C) MODIS and (D) VIIRS datasets. Box and whisker diagrams indicate the median, and 25th and 75th percentiles, respectively; open circles show outliers. No FRP values were recorded from January through April by the MODIS sensors or from January through March by the VIIRS sensors. Dotted lines indicate seasonal thresholds, and significant differences between months revealed by Wilcoxon post hoc rank sum test are denoted by letters a through d

occur if the burning was done later in the dry season (Pyne 1996). In reality, though, most of the area burns in the hot-dry season (Fig. 5) when fire intensity is at its highest (Sedano and Randerson 2014; N'dri et al. 2018). The burning program usually starts in the more accessible savanna portions of MWR, and this could explain in part why more of the savanna burns early in the cool-dry season compared to the miombo. However, the burning program has in the past not been completed before the end of July, leaving large areas to burn under hot, dry conditions accompanied by low fuel moisture in the hot-dry season. This has implications for the protection of vulnerable infrastructure, as well as for employees and tourists, and precautions should be taken to minimize these risks. Whether, and to what degree, managers will be able to change this pattern with the limited resources at their disposal needs to be assessed. Additionally, there is currently no local evidence to accurately assess whether or not the current fire regime, and the dominance of hot-dry season fires in particular, is detrimental to the ecosystem. It would therefore be important to maintain records of fire occurrence and monitor trends in ecosystem indicators (such as woody plant cover, and tree and large mammal mortality rates) so that the links between fires and ecological outcomes can be assessed, and clear targets for fire management can be adjusted to achieve intended ecological outcomes.

\section{Comparison to other African savannas}

Our findings support those of studies elsewhere, where it was found that fire return intervals are largely 
dependent on rainfall-driven fuel loads (van Wilgen et al. 2004; O'Connor et al. 2011) and herbivory (Archibald et al. 2005), and can thus show strong spatiotemporal variation across savanna Africa. This variation can be large, ranging from annual burns (Pricope and Binford 2012) to more than 30 years between fires (Bond and Archibald 2003). In many African savanna areas, total annual rainfall occurs in cycles of above- or belowaverage rainfall over several successive years. This implies that FRIs would be longer in dry cycles, and shorter in wet cycles. Our study also showed that, in line with findings elsewhere (van Wilgen et al. 2004), the total area burned in any given year was influenced by preceding rainfall. In our study, savannas in MWR had a mean FRI of $\sim 6$ yr. However, many areas had a shorter return interval of $<5 \mathrm{yr}$, as revealed by the median FRI of $3.1 \mathrm{yr}$. Nonetheless, almost $40 \%$ of savannas in MWR had FRIs $>10$ yr. Studies in other savanna areas have reported similar variation. For example, studies in the Kruger National Park, South Africa, have mostly reported mean FRIs between two and six years (van Wilgen et al. 2000; van Wilgen et al. 2004; Burkepile et al. 2013; Donaldson et al. 2018). A wider variety of median FRIs (i.e., the age at which $50 \%$ of the area will experience a successive fire) has also been reported, for example: $3.1 \mathrm{yr}$ in the Kruger National Park (van Wilgen et al. 2000), 1.3 yr in Hluhluwe-iMfolozi Park, South Africa (Balfour and Howison 2001), and $12.3 \mathrm{yr}$ in Mkhuze Game Reserve, South Africa (O'Connor et al. 2011). The reasons for this variation are not fully understood, but could include differences in rainfall patterns, grazing pressure, ignition sources, or the ratio of woody to herbaceous vegetation. Miombo in MWR has much shorter FRIs than savannas (mean $=\sim 4 \mathrm{yr}$, median $=1.7 \mathrm{yr})$, with few areas $(4.9 \%)$ surviving without fire for $>10 \mathrm{yr}$, and most (61.2\%) experiencing fire every 1 to 2 yr. This is likely due to the higher mean annual precipitation, as well as lower grazing pressures in miombo compared to savanna areas (Frost 1996), allowing grass fuels to accumulate more readily and fires to occur more frequently. It may therefore be appropriate for fire managers to set different targets for these different vegetation types. Previous estimates of FRIs in miombo were between 1.6 and 4 yr (Chidumayo 1995; Frost 1996; Saito et al. 2014; Ribeiro et al. 2018), but annual fires have also been recorded (Mwase et al. 2007). Rather than attempting to impose a fixed return interval over many years by setting a target of 30\% (in the case of MWR) of the area to burn each year, the target area to burn could be increased following wet rainfall cycles and reduced following dry cycles, and in some years, it may not be necessary to burn at all. Prescribed burning should also only be considered when grass fuel loads are sufficient to support a spreading fire, implying that they should be greater than $4000 \mathrm{~kg} \mathrm{ha}^{-1}$ (van Wilgen et al. 1998).
Fires in African savannas are furthermore characterized by a distinct seasonal pattern during which fuel loads become both available and flammable (Archibald et al. 2010), typically lasting for three to six months (Bradstock 2010). Similarly, fire intensity is seasonally dependent, typically peaking in the hot-dry season (September to November). In both miombo and savanna vegetation in MWR, these patterns were evident, and thus consistent with PAs in other African savanna ecosystems. For example, in Kruger National Park, a large proportion of the area (44\%) burned in only two months (September and October, van Wilgen et al. 2000), at which time fire intensity was at its highest as well (Govender et al. 2006). The same patterns were observed in Hluhluwe-iMfolozi Park (Balfour and Howison 2001) and in a miombo ecosystem (Roberston 1993).

\section{Comparison of the datasets}

Comparing data from the MODIS and VIIRS sensors has shown that more complete estimations of the total amount of area burned, and thus the estimated fire return intervals, as well as the seasonality of fires, can be made when combining these two datasets. This is due to the improved capability of the VIIRS satellite to detect large numbers of smaller fires (Schroeder et al. 2014; Blackett 2015) that are overlooked by the MODIS sensors. Using the MODIS data alone, the FRI for MWR for 2012 to 2019 was estimated to be $\sim 4.5 \mathrm{yr}$, compared to $\sim 7.6 \mathrm{yr}$ from the VIIRS data. The combined MODIS and VIIRS datasets placed the FRI at less than three years. Similarly, the VIIRS sensors revealed that substantial areas burned in the middle of the dry season (June to August), whereas the MODIS sensors confined most fires to the end of the dry season (September to October). This is almost certainly because the cool-dry season fires were smaller in size, and thus remained undetected by the MODIS satellite. Therefore, it seems that future studies would benefit from incorporating both products into their experimental design. However, the data collected by the VIIRS sensors is only available from 2012 onwards, and examinations of fire regimes further back in time will therefore have to depend on the coarser-scale MODIS data, or make use of the popular Landsat burned area product. Landsat data, however, have a lower temporal resolution compared to MODIS data (16-days versus daily cycle), and are therefore more suited for assessing post-fire changes in the landscape, rather than monitoring fires (Indratmoko and Rizqihandari 2019). MODIS data are nonetheless valuable for examining the broad features of past fire regimes prior to the introduction of VIIRS satellites. Previous fire studies that were based on MODIS instruments alone should be reexamined to assess the effect of smaller fires, which may make a substantial contribution to overall fire 
occurrences, on elements of the fire regime. That being said, the proportional distribution of fire, burned area, and fire intensity was similar in both MODIS and VIIRS estimates in this study. We can thus assume that these trends, as well as those observed between burned area and rainfall, and between miombo and savanna vegetation types, will not change depending on the choice of MODIS, VIIRS, or a combined dataset. Therefore, only estimates of total burned area (and thus FRIs) and fire probability are called into question, and were likely underestimated in this study, as well as previous studies based on MODIS data alone.

\section{Limitations}

Remote sensing has proved useful for assessing the past fire regime of MWR, which will in turn be useful for informing the development of appropriate fire management policies. Limitations to the approach include the possibility that some fires may have been overlooked due to intense cloud cover, smoke, or dense canopies (Roy et al. 2008), or that the satellite sensors would have been unable to detect fires if they were too small, or if they started and ended between times of overpass (Giglio et al. 2018b). While these potential errors may be acceptable in a long-term fire regime assessment such as the one reported here, the size of the error cannot be accurately assessed. Roy and Boschetti (2009) estimated that the MCD45A1 product was able to detect $\sim 75 \%$ of burned area in southern Africa. Other information, such as the cause of fire, also cannot be assessed by remote sensing. The results of this study were also restricted by the temporal scale for which datasets were available (19 years for MODIS and eight years for VIIRS). There is thus no information on fire occurrence available prior to 2001, but as our study area is characterized by relatively short FRIs, the timescales used here are likely more than adequate to understand the broad fire regimes in this area. Finally, the FRP measures are unlikely to capture maximum fire intensity values, potentially leading to underestimates of fire intensity (Kumar et al. 2011).

\section{Acknowledgements}

WAN thanks African Parks Ltd. for logistical support.

\section{Authors' contributions}

This study was collaboratively conceived and designed by all authors. WAN sourced the data, conducted the analyses, and co-wrote the paper with BWVW. All authors read and approved the final manuscript.

\section{Funding}

This study was funded by the Earthwatch Institute (grant to AJL), under the Majete Wildlife Research Programme, Malawi; the DST-NRF Centre of Excellence for Invasion Biology; and the National Research Foundation of South Africa (grant 109467 to BWVW). None of the funding bodies played any role in the design of the study, or collection, analysis, or interpretation of data, or in writing the manuscript.

\section{Availability of data and materials}

The data that support the findings of this study are available from the Land Processes Distributed Active Archive Center (LP-DAAC) at http://reverb.echo. nasa.gov/, http://modis-fire.umd.edu/, and https://pdaac.usgs.gov/.

Ethics approval and consent to participate

Not applicable.

Consent for publication

Not applicable.

\section{Competing interests}

The authors declare that they have no competing interests.

\section{Author details}

'Department of Conservation Ecology and Entomology, Stellenbosch University, Private Bag X1, Matieland, Western Cape 7602, South Africa. ${ }^{2}$ Majete Research Programme, Majete Wild life Reserve, P.O. Box 232, Chikwawa 315100, Malawi. ${ }^{3}$ Centre for Invasion Biology, Department of Botany and Zoology, Stellenbosch University, Private Bag X1, Matieland 7602, South Africa.

Received: 22 April 2020 Accepted: 16 December 2020

Published online: 26 January 2021

\section{References}

Anderson, T.M., M.E. Ritchie, E. Mayemba, S. Eby, J.B. Grace, and SJ. Mcnaughton. 2007. Forage Nutritive Quality in the Serengeti Ecosystem: The Roles of Fire and Herbivory. American Naturalist 170: 343-357 https://doi.org/10.1086/520120.

Archibald, S., H. Beckett, W.J. Bond, C. Coetsee, D.J. Druce, and C.A. Staver. 2017. Interactions between Fire and Ecosystem Processes, Conserving Africa's MegaDiversity in the Anthropocene: The Hluhluwe-iMfolozi Park Story. Cambridge: Cambridge University Press.

Archibald, S., W.J. Bond, W.D. Stock, and D.H.K. Fairbanks. 2005. Shaping the landscape: fire-grazer interactions in an African savanna. Ecological Applications 15: 96-109 https://doi.org/10.1890/03-5210.

Archibald, S., and G.P. Hempson. 2016. Competing consumers: contrasting the patterns and impacts of fire and mammalian herbivory in Africa. Philosophical Transactions of the Royal Society B: Biological Sciences 371: 20150309 https:// doi.org/10.1098/rstb.2015.0309.

Archibald, S., D.P. Roy, B.W. van Wilgen, and R.J. Scholes. 2009. What limits fire? An examination of driver's of burnt area in Southern Africa. Global Change Biology: 1-18 https://doi.org/10.1111/j.1365-2486.2008.01754.x.

Archibald, S., R.J. Scholes, D.P. Roy, G. Roberts, and L. Boschetti. 2010. Southern African fire regimes as revealed by remote sensing. International Journal of Wildfire Fire 19: 774-782 https://doi.org/10.1071/WF10008.

Balfour, D.A., and O.E. Howison. 2001. Spatial and temporal variation in a mesic savanna fire regime: Responses to variation in annual rainfall. African Journal of Range and Forage Science 19: 45-53. https://doi.org/10.2989/10220110209485773.

Barrett, K, and E.S. Kasischke. 2013. Controls on variations in MODIS fire radiative power in Alaskan boreal forests: Implications for fire severity conditions. Remote Sensing of Environment 130: 171-181 https://doi.org/10.1016/..rse.2012.11.017.

Blackett, M. 2015. An initial comparison of the thermal anomaly detection products of MODIS and VIRS in their observation of Indonesian volcanic activity. Remote Sensing of Environment 171: 75-82 https://doi.org/10.1016/.jse.2015.10.002.

Bond, W.J., and S. Archibald. 2003. Confronting complexity: fire policy choices in South African savanna parks. International Journal of Wildland Fire 12 (4): 381 389 https://doi.org/10.1071/WF03024.

Bond, W.J., and J.E. Keeley. 2005. Fire as a global "herbivore": The ecology and evolution of flammable ecosystems. Trends in Ecology \& Evolution 20: 387394. https://doi.org/10.1016/j.tree.2005.04.025.

Bradstock, R.A. 2010. A biogeographic model of fire regimes in Australia: current and future implications. Global Ecology and Biogeography 19 (2): 145-158 https://doi.org/10.1111/j.1466-8238.2009.00512.x.

Brockett, B.H., H.C. Biggs, and B.W. van Wilgen. 2001. A patch mosaic burning system for conservation areas in southern African savannas. International Journal of Wildland Fire 10: 169-183 https://doi.org/10.1071/WF01024.

Burkepile, D.E., C.E. Burns, CJ. Tambling, E. Amendola, G.M. Buis, N. Govender, V. Nelson, D.I. Thompson, A.D. Zinn, and M.D. Smith. 2013. Habitat selection by large herbivores in a southern African savanna: the relative roles of bottom-up and top-down forces. Ecosphere 4 (11): 1-19 https//doi.org/10.1890/ES13-00078.1. 
Chidumayo, E.N. 1995. Handbook of Miombo ecology and management. Stockholm Environmental Institute, Sweden. https://doi.org/10.3362/9781780445496.000.

Donaldson, J.E., S. Archibald, N. Govender, D. Pollard, Z. Luhdo, and C.L. Parr. 2018. Ecological engineering through fire-herbivory feedbacks drives the formation of savanna grazing lawns. Journal of Applied Ecology 55 (1): 225235 https://doi.org/10.1111/1365-2664.12956.

Eby, S.L., J. Dempewolf, R.M. Holdo, and K.L. Metzger. 2015. Fire in the Serengeti ecosystem: history, drivers, and consequences, in: Serengeti N: Sustaining Biodiversity in a Coupled Human-Natural System. Chicago: The University of Chicago Press.

Fornacca, D., R. Guopend, and X. Wen. 2017. Performance of three MODIS fire products (MCD45A1, MCD64A1, MCD14ML), and ESA Fire_CCl in a mountainous area of northwest Yunnan, China, characterised by frequent small fires. Remote Sensing 9: 1131 https://doi.org/10.3390/rs9111131.

Forsyth, G.G., and B.W. van Wilgen. 2008. The recent fire history of the Table Mountain National Park and implications for fire management. Koedoe 50 (2): 3-9 https://doi.org/10.4102/koedoe.v50i1.134

Frost, P. 1996. The ecology of Miombo woodlands. In The Miombo in Transition: woodlands and welfare in Africa, ed. B. Campbell, 11-57. Bogor, Indonesia: Centre for International Forestry Research.

Giglio, L., L. Boschetti, D.P. Roy, M.L. Humber, and C.O. Justice. 2018a. The Collection $6 \mathrm{MODIS}$ burned area mapping algorithm and product. Remote Sensing of environment 217: 72-85 https://doi.org/10.1016/j.rse.2018.08.005.

Giglio, L., W. Schroeder, J.V. Hall, and C.O. Justice. 2018b. MODIS Collection 6 active fire product user's guide revision $B, 1-64$.

Goodwin, N.R., and L.J. Collett. 2014. Development of an automated method for mapping fire history captured in Landsat TM and ETM+ time series across Queensland, Australia. Remote Sensing of Environment 148: 206-221 https:// doi.org/10.1016/j.rse.2014.03.021.

Govender, N., W.S.W. Trollope, and B.W. van Wilgen. 2006. The effect of fire season, fire frequency, rainfall and management on fire intensity in savanna vegetation in South African. Journal of Applied Ecology 43: 748-758. https:// doi.org/10.1111/j.1365-2664.2006.01184.x.

Hall-Martin, A. 1972. Classification and ordination of forest and thicket vegetation of the Lengwe National Park, Malawi. Kirkia 10: 131-144.

Higgins, S.I., W.J. Bond, E.C. February, A. Bronn, D.I. Euston-Brown, B. Enslin, N. Govender, L. Rademan, S. O'Regan, A.L. Potgieter, and S. Scheiter. 2007. Effect of four decades of fire manipulation on woody vegetation structure in savanna. Ecology 88: 1119-1125 https://doi.org/10.1890/06-1664.

Ichoku, C., L. Giglio, M.J. Wooster, and L.A. Remer. 2008. Global characterization of biomass-burning patterns using satellite measurements of fire radiative energy. Remote Sensing and Environment 112 (6): 2950-2962 https://doi.org/ 10.1016/j.rse.2008.02.009.

Indratmoko, S., and N. Rizqihandari. 2019. Burn Area Detection Using Landsat 8 OLI TIRS. In IOP Conference Series: Earth and Environmental Science, Vol. 338, No. 1, 012035. IOP Publishing. https:/doi.org/10.1088/1755-1315/338/1/012035

Kaufman, Y.., L. Remer, R. Ottmar, D. Ward, L. Rong-R, and R. Kleidman. 1996. Relationship between remotely sensed fire intensity and rate of emission of smoke: SCAR-C experiment. In Global biomass burning, ed. J. Levine, 685-696. Massachusetts: MIT Press.

Kruskal, W.H., and W.A. Wallis. 1952. Use of ranks in one-criterion variance analysis. Journal of the American Statistical Association 47 (260): 583-621 https://doi. org/10.1080/01621459.1952.10483441.

Kumar, S.S., D.P. Roy, L. Boschetti, and R. Kremens. 2011. Exploiting the power law distribution properties of satellite fire radiative power retrievals: A method to estimate fire radiative energy and biomass burned from sparse satellite observations. Journal of Geophysical Research: Atmospheres 116 (D19) https:/doi.org/10.1029/2011JD015676.

Morris, B. 2006. The history and conservation of mammals in Malawi (Monograph No. 21). Zomba, Malawi: Kachere Series.

Mwase, W.F., A. Bjørnstad, J.M. Bokosi, M.B. Kwapata, and B. Stedje. 2007. The role of land tenure in conservation of tree and shrub species diversity in miombo woodlands of southern Malawi. New Forests 33 (3): 297-307 https://doi.org/10.1007/s11056-0069029-0.

N'dri, A.B., T.D. Soro, J. Gignoux, K. Dosso, M. Koné, J.K. N'dri, and S. Barot. 2018. Season affects fire behaviour in annually burned humid savanna of West Africa. Fire Ecology 14 (2): 5 https://doi.org/10.1186/s42408-018-0005-9.

NSOM UNFPA. [National Statistical Office of Malawi, United Nations Population Fund.]. 2018. Malawi Population and Housing Census. Zomba, Malawi: National Statistical Office.

O'Connor, T.G., C.M. Mulqueeny, and P.S. Goodman. 2011. Determinants of spatial variation in fire return period in a semiarid African savanna. International Journal of Wildland Fire 20 (4): 540-549 https://doi.org/10.1071/WF08142.
Pricope, N.G., and M.W. Binford. 2012. A spatio-temporal analysis of fire recurrence and extent for semi-arid savanna ecosystems in southern Africa using moderate-resolution satellite imagery. Journal of Environmental Management 100: 72-85 https://doi.org/10.1016/j.jenvman.2012.01.024.

Pyne, S.J. 1996. Wild hearth a prolegomenon to the cultural fire history of northern Eurasia. In Fire in ecosystems of Boreal Eurasia, 21-44. Dordrecht: Springer https://doi.org/10.1007/978-94-015-8737-2_2.

Ribeiro, N.S., A. Cangela, A. Chauque, R.R. Bandeira, and A.I. Ribeiro-Barros. 2018. Characterisation of spatial and temporal distribution of the fire regime in Niassa National Reserve, northern Mozambique. International Journal of Wildland Fire 26 (12): 1021-1029 https://doi.org/10.1071/WF17085.

Roberston, F. 1993. Early-burning in the Brachystegia woodland of the Parks and Wild Life Estate. Zimbabwe Science News 27 (7-9): 68-71.

Rogers, B.M., A.J. Soja, M.L. Goulden, and J.T. Randerson. 2015. Influence of tree species on continental differences in boreal fires and climate feedbacks. Nature Geoscience 8 (3): 228-234 https://doi.org/10.1038/ngeo2352.

Roy, D., and L. Boschetti. 2009. Southern Africa validation of the MODIS, L3JRC and Glob- Carbon Burned Area Products. Transactions on Geoscience and Remote Sensing. https://doi.org/10.1109/TGRS.2008.2009000.

Roy, D., L. Boschetti, C. Justice, and J. Ju. 2008. The collection 5 MODIS burned area product - Global evaluation by comparison with the MODIS active fi20 product. Remote Sensing of Environment https://doi.org/10.1016/.rse.2008.05.013.

RStudio Team. 2020. RStudio: integrated development for R. Boston, Massachusetts, USA: RStudio, PBC http://www.rstudio.com/.

Saito, M., S. Luyssaert, B. Poulter, M. Williams, P. Ciais, V. Bellassen, C.M. Ryan, C. Yue, P. Cadule, and P. Peylin. 2014. Fire regimes and variability in aboveground woody biomass in miombo woodland. Journal of Geophysical Research: Biogeosciences 119 (5): 1014-1029 https:/doi.org/10.1002/2013JG002505.

Scholes, R.J., and B.H. Walker. 1993. An African savanna: synthesis of the Nylsvley study. Cambridge University Press. https://doi.org/10.1017/CBO9780511565472.

Schroeder, W. P. Olivia, L. Giglio, and I.A. Csiszar. 2014. The new VIIRS 375 m active fire detection data product: Algorithm description and initial assessment. Remote Sensing of Environment 143: 85-96 https://doi.org/10.1016/j.rse.2013.12.008.

Sedano, F., and J.T. Randerson. 2014. Multi-scale influence of vapor pressure deficit on fire ignition and spread in boreal forest ecosystems. Biogeosciences 11 (14): 3739-3755 https://doi.org/10.5194/bg-11-3739-2014.

Sherry, B.Y. 1989. Aspects of the ecology of the elephant Loxodonta africana (Blumenbach, 1971) in the Middle Shire Valley, southern Malawi. (Unpublished M.Sc. thesis). Zomba, Malawi: University of Malawi.

Staub, C.G., M.W. Binford, and F.R. Stevens. 2013. Elephant herbivory in Majete Wildlife Reserve, Malawi. African Joumal of Ecology 51 (4): 535-543 https//doi.org/10.1111/aje.12064.

van Wilgen, B.W. 2009. The evolution of fire management practices in savanna protected areas in South Africa. South African Journal of Science 105: 343-349 https://doi.org/10.4102/sajs.v105i9/10.107.

van Wilgen, B.W., H.C. Biggs, S.P. O'Regan, and N. Mare. 2000. A fire history of the savanna ecosystems in the Kruger National Park, South Africa, between 1941 and 1996. South African Journal of Science 96: 167-178.

van Wilgen, B.W., H.C. Biggs, and A.L.F. Potgieter. 1998. Fire management and research in the Kruger National Park, with suggestions on the detection of thresholds of potential concern. Koedoe: African Protected Area Conservation 41: 69-87 https://doi.org/10.4102/koedoe.v41i1.248.

van Wilgen, B.W., N. Govender, D. Ntsala, and X.N. Funda. 2004. Response of Savanna Fire Regimes to Changing Fire-Management Policies in a Large African. Conservation Biology 18: 1533-1540 https:/doi.org/10.1111/j.1523-1739.2004.00362.x.

Wilcoxon, F. 1945. Individual comparisons by ranking methods. Biometrica Bulletin 1: 80-83 https://doi.org/10.2307/3001968.

Wooster, M.J., G. Roberts, G.L.W. Perry, and Y.J. Kaufman. 2005. Retrieval of biomass combustion rates and totals from fire radiative power observations: FRP derivation and calibration relationships between biomass consumption and fire radiative energy release. Journal of Geophysical Research: Atmospheres 110 (D24) https://doi.org/10.1029/2005JD006318.

Wooster, M.J., G. Roberts, A.M. Smith, J. Johnston, P. Freeborn, S. Amici, and A.T. Hudak. 2013. Thermal remote sensing of active vegetation fires and biomass burning events. In Thermal infrared remote sensing, 347-390. Dordrecht: Springer https://doi.org/10.1007/978-94-007-6639-6_18.

\section{Publisher's Note}

Springer Nature remains neutral with regard to jurisdictional claims in published maps and institutional affiliations. 